\title{
奄美大島沿岸における干潟底生生物相
}

\section{Macrobenthic Fauna in the Tidal Flats of Amami-Oshima Island}

\author{
緒方沙帆 ${ }^{1)} \cdot$ Rocille PALLA ${ }^{1)} \cdot$ 上野綾子 ${ }^{2)}$ ・佐藤正典 ${ }^{3 ）}$ ・鈴木廣志 ${ }^{4)} \cdot$ 山本智子 ${ }^{4), *}$ \\ 1) 鹿児島大学大学院水産学研究科。广 $890-0056$ 鹿児島県鹿児島市下荒田 4 丁目 50-20 \\ 2) 鹿児島大学大学院連合農学研究科。 $\overline{7} 890-0056$ 鹿児島県鹿児島市下荒田 4 丁目 50-20 \\ 3) 鹿児島大学理学部。 $\bar{T} 890-8580$ 鹿児島県鹿児島市郡元 1 丁目 21 番 25 号 \\ 4) 鹿児島大学水産学部。广 890-0056 鹿児島県鹿児島市下荒田 4丁目 50-20
}

\author{
Shiho OGATA ${ }^{1)}$, Rocille PALLA ${ }^{1)}$, Ryoko UENO ${ }^{2)}$, Masanori SATO ${ }^{3)}$, Hiroshi SUZUKI ${ }^{4)}$ and \\ Tomoko YAMAMOTO ${ }^{4) * *}$ \\ 1) The Graduate School of Fisheries, Kagoshima University, 4-50-20 Shimoarata, Kagoshima 890-0056, Japan \\ 2) The United Graduate School of Agricultural Sciences, Kagoshima University, 4-50-20 Shimoarata, Kagoshima 890-0056, Japan \\ 3) Faculty of Science, Kagoshima University, 1-21-25 Korimoto, Kagoshima 890-8580, Japan \\ 4) Faculty of Fisheries, Kagoshima University, 4-50-20 Shimoarata, Kagoshima 890-0056, Japan
}

\begin{abstract}
The Amami Islands are located south of Japan's main islands and their inherent fauna and flora have high species diversity. In order to augment our limited knowledge on the coastal benthic fauna of these islands, we investigated the macrobenthic fauna in four tidal flats on Amami-Oshima Island. A total of 123 species or taxa ware sampled at the four study sites, with the number of species at each site varying from 39 to 89. Species richness was highest at Tekebu-higata tidal flat (the northernmost study site) and lowest at Ichi-higata tidal flat (central Amami). Yanyu-higata in the northern part of the island, and Kunetsu-higata, the southernmost study site, had intermediate species richness. The density of benthic animals was lowest at Yanyu-higata and highest at Kunetsu-higata. The local diversity, the mean number of species at a station, did not vary markedly among the study sites (ranging from 3.35 to 4.79), whereas the species richness of tidal flats tended to differ among the study sites. This indicates that the species diversity of the tidal flats can be attributed to the diversity among stations ( $\beta$ diversity). The heterogeneity of benthic community is discussed in relation to tidal flat sediment condition.
\end{abstract}

Key Words: tidal flat, Amami-Oshima Island, species richness, microbenthos, $\beta$ diversity

\section{はじめに}

鹿児島県南部に位置する奄美群島は，日本国内で確認さ れている生物種約 37,000 種のうち約 16\%が生息するなど, 高い生物多様性を有することが知られている．また，奄美 群島独自の固有種も多く, 昆虫類 1038 種, 維管束植物 38 種, 哺乳類 10 種を含む 1147 種の固有種が確認されており （奄美大島生物多様性地域戦略策定運用協議会 2015）, 2017 年に奄美群島国立公園に指定された。このような高い生物 多様性と固有性や，黒潮の影響による湿潤な亜熱帯雨林が 発達していることが注目され,「奄美・琉球」地域として 世界自然遺産候補にも挙げられている。底生生物において も, 汽水や淡水域を中心に, 甲殼類や貝類で多くの希少種 が分布する事が知られている（WWF ジャパン 2009; 日本

Received 18 February 2016 Accepted 16 May 2017

* Corresponding author

E-mail: yamamoto@fish.kagoshima-u.ac.jp
ベントス学会 2012; 鹿児島県環境林務部自然保護課 2016). しかしながら, 分布情報が希少種に限られており, この地 域の底生生物相や多様性を明らかにするのに十分とは言い 難い.

地域の底生生物相を扱った研究では, 干潟の貝類（名和 2008), 干潟の甲殼類と貝類 (三浦・三浦 2015), 汽水性甲 殸類（岸野ら 2001）, 陸水貝類（増田・早瀬 2000; 木村 木村 2008）など特定の分類群に焦点が絞られており, 底生 生物群集を対象とした調査はあまり行われていない，環境 省が行った浅海域生態系調査（干潟調査）では奄美大島の 2 地点で干潟の底生生物相が調査されているが, 各種の有 無又は多寡にとどまっており, 定量的な調査がなされてい るとは言えない（環境省自然保護局・生物多様性センター 2007).

干潟は沿岸域において陸域と海域をつなぐエコトーンと して機能しており，そこに生息する底生生物群集は食物連 鎖を通してこの機能を支えているとされている（菊池 1993）. しかしながら，近年，日本全国で干潟の面積は大幅に減少 してきており（環境庁自然保護局 1994），鹿児島県もその 
例外ではない，鹿児島湾奥では，1977 年には 200 ha 程あっ た干潟が 2003 年には 60 ha に減少している（山本・小玉 2009)。また, 表在性であるウミニナ Batillaria multiformis などの腹足類の個体数が増加し埋在性である二枚貝類が激 減するなど, 干潟の環境変動による底生生物相の変化が著 しい（山本ら 2009）。奄美大島でも，前述した海岸線の人 工改変が盛んに行われてきており, 北部の手花部干潟で は, 1978 年から 1992 年までに干潟面積が約 74 ha から約 50 ha まで減少している（環境庁自然保護局 1994）。このこ とは，奄美大島の貴重な海岸生物が十分に調査されないま まハビタットの消失とともに失われてしまう可能性を示唆 している。

干潟の底生生物相は, 低潮位からの地盤高や干満の潮位 差, 底質粒度や粒度組成を決定付ける恒常的な流動環境及 び豪雨出水などの突発的要因など複数の影響を受けて決ま るとされており（菊池 1993）, 同じ島内でも干潟間で底生 生物相は異なると予想される。，そのため, 奄美大島全域の 干潟底生生物相を捉えるためには, 環境の異なる複数の干 潟で調査を行う必要がある。

また, 一般に, 底生生物の分布に影響を与える環境要因 は同一海岸内でも空間的な変異を持ち, それによって底生 生物群集の空間構造が作り出される。例えば, 岩礁潮間帯 では, 乾燥や高低温をさけるための微小地形がそしいた め, 干出時間の長いほど長時間の乾燥や極端な温度変化に 晒されることになる。したがって, 垂直方向の環境変異, 高度が生物相の分布パターンに大きな影響を与える（ラ ファエリ・ホーキンズ 1999; Okuda et al. 2004). 干潟は岩 礁潮間帯などに比べ高度の変化が緩やかなため, 底質環境 や植生の有無, 河川からの距離といった高度以外の環境要 因が底生生物の分布に与える影響が岩礁潮間帯に比して大 きいと考えられる。このような環境要因の空間変異が干潟 内の底生生物の分布に空間構造をもたらし, 干潟全域の底 生生物の多様性に貢献していると考えられる（宮下・野田 2003)。そのため, 干潟の底生生物相を調査するにあたっ
ては, 干潟内の環境変異を考慮し, それによって群集構造 に空間構造がもたらされる可能性にも注意する必要があ る.

そこで本研究では, 奄美大島の干潟における底生生物相 を明らかにすることを目的として島内 4 ヶ所の干潟におい て調査を行い, 干潟全体の種多様性がどのようにして形成 されているのかについて, 干潟内における群集の空間構造 や環境要因の空間変異との関連を考察した。

\section{調査地と方法}

\section{調査地の概要}

調査地としては, 地図と航空写真からある程度の広さが ある干潟を抽出し, その中から, 陸からのアクセスが可能 な 4 ヶ所を選定した. 鹿児島県奄美市笠利町の手花部干 潟, 龍郷町の屋入干潟, 奄美市住用町の市干潟, 瀬戸内町 の久根津干潟の 4 海岸である (Fig. 1). 調査は, 手花部干 潟で 2013 年 5 月と 7 月, 屋入干潟, 久根津干潟で 2014 年 5 月, 市干潟で 2014 年 7 月に行った.

手花部干潟での調査は, 手花部川と坂下川にはさまれた 干潟中央部で行った. 航空写真から算出したこの部分の面 積は約 $67,500 \mathrm{~m}^{2}$ である. 潮間帯下部を中心にサンゴ砂が 点在しており, 坂下川下流にはマングローブが生育してい た. 屋入干潟の西側には屋入川が流れ込んでおり, 潮間帯 上部には転石帯が広がっているが, 中下部は底質が粗く小 石が多い. 屋入川から東側の約 $23,300 \mathrm{~m}^{2}$ の干潟で調査を 行った。市干潟は, 全域に細かい底質が広がる泥干潟であ り, 東側にマングローブの低木が群生していた。調査は西 側の約 $9,900 \mathrm{~m}^{2}$ の干潟で行ったが, 潮間帯上部は乾燥し て砂浜に近い状態であった。 久根津干潟は海側に張り出し た住宅を境に南北に 2 分される形になっており, 南側の約 $6,800 \mathrm{~m}^{2}$ で調査を行った。潮間帯上部は砂干潟, 下部は泥 干潟であった.

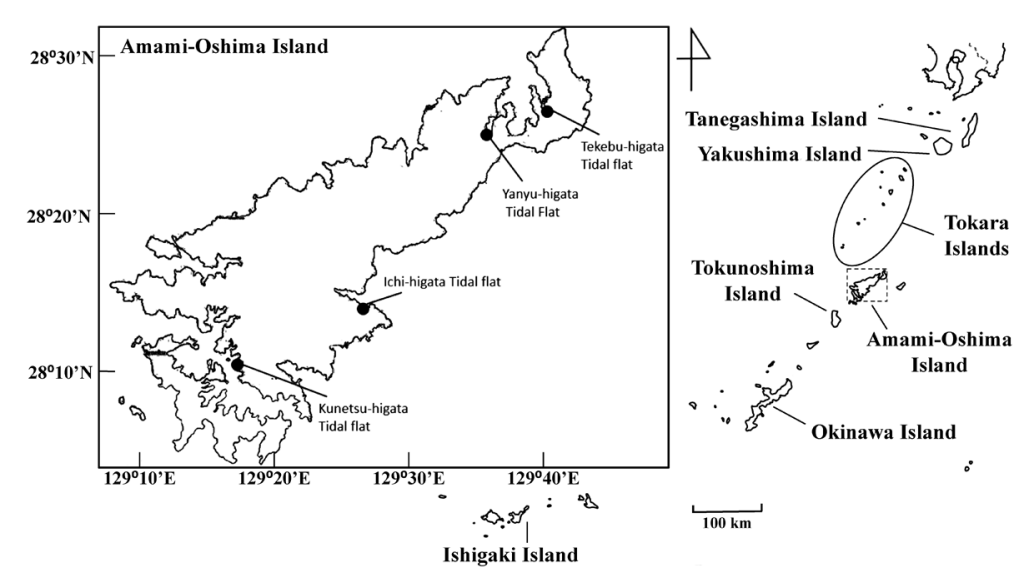

Fig. 1. Map showing the location of the study sites. Islands from the southern Kyushu to Yaeyama Islands are shown on the right of figure. The map on the left of the figure is an enlargement of Amami-Oshima Island and shows the locations of the four study sites. 


\section{底生生物の分布調査}

各干潟で，底生生物を対象とした定量的調查と定性的調 査を行った。定性的調査では, 干潟全域を面積に応じて 2 つ以上のエリアに分け，それぞれのエリアで 15 分間の 採集を行った。エリア内を 15 分間 4 人でそれぞれ満遍な く歩き回り, 底質上で目についた生物や底質を掘り返して 出てきた生物を採集した（日本国際湿地連合 2011）。採集 した生物は, その場で種がわかるものについては 1 種類に つき1 個体を，わからないものに関してはすべてを $70 \%$ エタノールで固定し, 研究室に持ち帰り同定を行った。こ の調査は, 各干潟における底生生物の種リストを作成する ことを目的としている.

定量的調査では，それぞれの干潟で一定面積を採集する ことによって, 底生生物各種の現存量を調査した。各干潟 で, 潮間帯上部から下部にかけて海岸線に対して垂直のラ インを設置し，その上に等間隔でステーションを設置した。 ラインの本数とステーションの間隔は干潟の面積と形状に 応じて決定したが，いずれも計 24 ケ所のステーションが 設置出来るように配置した. 手花部干潟ではラインを 5 本 設置し, そのライン上 $40 \mathrm{~m}$ 間隔にステーションを設置し た. 他の干潟ではラインを 4 本設置し, 屋入干潟では $25 \mathrm{~m}$ 間隔，市干潟では $15 \mathrm{~m}$ 間隔，久根津干潟では $20 \mathrm{~m}$ 間隔で ステーションを設置した. 各ラインとステーションの位置 は, 結果とともに Fig. 3〜Fig. 6 に示す.

各ステーションで直径 $17 \mathrm{~cm}$ のコアを 3 個用いて深さ $10 \mathrm{~cm}$

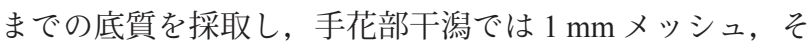

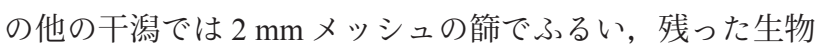
を採集した。後者は底質の粒度が粗くほとんどの底質が篩 上に残ってしまうため, より粗いメッシュを使わざるを得 なかった．採集した生物のうち同定が容易なものはその場 で計数の後放流し, 他は $70 \%$ エタノルで固定した上で 研究室に持ち帰り, 種または分類群別に計数した.

手花部干潟でのみ $1 \mathrm{~mm}$ メッシュを使用していることに 関して，以下の方法でメッシュサイズと採集効率に関する
検証を行った。手花部干潟の 5 つのステーションで, 直径 $17 \mathrm{~cm}$ のコアを 3 個用いて深さ $15 \mathrm{~cm}$ までの底質を採取し， その中の堆積物を $2 \mathrm{~mm}$ メッシュの下に $1 \mathrm{~mm}$ メッシュの 篩を重ねてふるい, それぞれに残った生物を採集，比較し

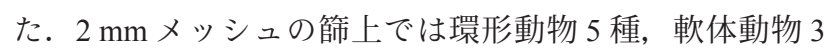
種, 節足動物 2 種が, $1 \mathrm{~mm}$ メッシュの篩上では環形動物 3 種が採集された（Table 1). 5 ステーションのうち 2 つの ステーションで, $2 \mathrm{~mm}$ メッシュ上より多数の個体が $1 \mathrm{~mm}$ メッシュ上で採取された。特に, スピオ科 Spionidae spp.

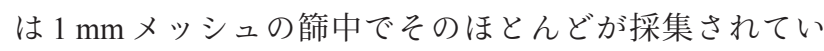

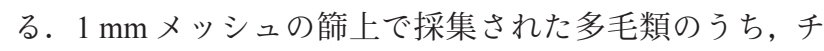
ロリ科 Glyceridae spp.とゴカイ科 Nereididae spp.は $2 \mathrm{~mm}$ メッシュ上でも採集された. $2 \mathrm{~mm}$ メッシュを抜けて $1 \mathrm{~mm}$ メッシュ上で多く採集された底生生物は，スピオ科の多毛 類のみであった。この分類群はこの検証実験の際に多個体 が採集され, $1 \mathrm{~mm}$ メッシュで手花部干潟を調査した際には ほとんど採集されていないことから，定量的調査の結果に は影響していないものと考えられる. 検証実験は 9 月, 定 量的調查は 5 月と 7 月に行っており, ある季節に行った調 査ではメッシュサイズが採集結果に影響を与える可能性は あるが，今回の調査には当てはまらないと判断した。

なお，ウミニナ属腹足類については，奄美大島ではウミ ニナとリュウキュウウミニナ Batillaria flectosiphonata とい う近縁 2 種が同所的に分布しており，両者を形態から区別 することは極めて困難であること, 遺伝子解析により, 少 なくとも手花部干潟では両種が混在する（Hirose et al. 2014）ことが分かっていることから，ここでは 2 種の区別 をしないものとした.

\section{底質採集と各測定方法}

生物調査を行った各ステーションで, 深さ $3 \mathrm{~cm}$ までの底 質を採集し, 含水率, 有機物含有量 (強熱減量), 粒度組 成の測定に用いた。湿重量を測定後 $120^{\circ} \mathrm{C}$ で 12 時間加熱 し, 乾重量を測定した後, 両者の差が質重量に占める割合

Table 1. List of benthic species sampled in Tekebu-higata tidal flat using meshes of different size. Numbers of each taxon separated from sediments sampled by using three cores $(17 \mathrm{~cm}$ diameter $)$ at each station. A sieve with 2-mm mesh was lapped over a 1-mm mesh sieve. The numbers of individuals remaining on each sieve are shown in the table.

\begin{tabular}{|c|c|c|c|c|c|c|c|c|c|c|}
\hline \multirow{2}{*}{$\begin{array}{c}\text { Station } \\
\text { Sieve mesh size }\end{array}$} & \multicolumn{2}{|c|}{ Line $A 0 \mathrm{~m}$} & \multicolumn{2}{|c|}{ LineB $120 \mathrm{~m}$} & \multicolumn{2}{|c|}{ LineC $0 \mathrm{~m}$} & \multicolumn{2}{|c|}{ LineD $200 \mathrm{~m}$} & \multicolumn{2}{|c|}{ LineE $120 \mathrm{~m}$} \\
\hline & $1 \mathrm{~mm}$ & $2 \mathrm{~mm}$ & $1 \mathrm{~mm}$ & $2 \mathrm{~mm}$ & $1 \mathrm{~mm}$ & $2 \mathrm{~mm}$ & $1 \mathrm{~mm}$ & $2 \mathrm{~mm}$ & $1 \mathrm{~mm}$ & $2 \mathrm{~mm}$ \\
\hline Ostreidae sp. & 0 & 0 & 0 & 0 & 0 & 0 & 0 & 0 & 0 & 1 \\
\hline Gafrarium tumidum & 0 & 0 & 0 & 0 & 0 & 0 & 0 & 0 & 0 & 1 \\
\hline Veneridae sp. & 0 & 1 & 0 & 0 & 0 & 0 & 0 & 0 & 0 & 0 \\
\hline Glyceridae spp. & 0 & 0 & 1 & 0 & 0 & 0 & 0 & 1 & 0 & 0 \\
\hline Nereididae spp. & 0 & 1 & 0 & 1 & 0 & 0 & 1 & 2 & 0 & 10 \\
\hline Spionidae spp. & 0 & 0 & 35 & 4 & 8 & 0 & 0 & 0 & 3 & 0 \\
\hline Heteromastus sp. & 0 & 0 & 0 & 0 & 0 & 0 & 0 & 2 & 0 & 0 \\
\hline Polychaeta spp. & 0 & 0 & 0 & 0 & 0 & 0 & 0 & 7 & 0 & 0 \\
\hline Leptodius distinguendus & 0 & 0 & 0 & 1 & 0 & 0 & 0 & 0 & 0 & 0 \\
\hline Macrophthalms verreauxi & 0 & 0 & 0 & 2 & 0 & 0 & 0 & 0 & 0 & 0 \\
\hline
\end{tabular}


から含水率を算出した．このサンプルを 2 組に分け，一方 はその後 $650^{\circ} \mathrm{C} て ゙ 2$ 時間燃焼させ, 減少した重量の割合を 強熱減量とした。もう一方は $120^{\circ} \mathrm{C} て ゙ ~ 12$ 時間乾燥させた 後, 振とう器を使用し, 粒子を $<0.063 \mathrm{~mm}, 0.063 \mathrm{~mm} \sim$ $0.125 \mathrm{~mm}, 0.125 \mathrm{~mm} \sim 0.25 \mathrm{~mm}, 0.25 \mathrm{~mm} \sim 0.5 \mathrm{~mm}, 0.5 \mathrm{~mm} \sim$ $1 \mathrm{~mm}, 1 \mathrm{~mm} \sim 2 \mathrm{~mm}, 2 \mathrm{~mm}>$ の 7 区分に分けた. 各サイズ クラスの重量を計量し, 全体に占める割合を算出して粒度 組成とするとともに, その值から中央粒径值を求めた.

\section{解析方法}

ここでは, 群集の多様性を表す指標として, 定量的調査 の結果を用いて, 各ステーション（ $\alpha$ 多様性）と干潟全体 （誃様性）の異なる空間スケールにおける種数を比較した. $\alpha$ 多様性はステーション当たりの出現種数の平均值, $\gamma$ 多様 性は干潟全体の種数で表し, $\gamma$ 多様性を $\alpha$ 多様性で割った值 （ $\beta$ 多様性）は局所群集間の多様性を示す（宮下・野田 2003).

また, 以下の式を用いて, 各干潟の種多様性を算出した (木元・武田 1989).

\section{Simpson の多様度指数}

$$
D=1-\sum_{i=1}^{s} p_{i}^{2}
$$

Shannon-Wiener の多様度指数

$$
H^{\prime}=-\sum_{i=1}^{s} p_{i} \ln p_{i}
$$

ただし, $p i$ は各干潟における $i$ 番目の種又は分類群が群集 全体に占める個体数の割合を示す.

各ステーションの底生生物群集データ及び粒度組成の データ（各サイズクラスが占める重量の重量割合）を用い てクラスター解析を行い, 4 干潟計 96 ヶ所のステーション を群集組成と粒度組成によって分類した。ただし, 群集組 成の解析においては, ステーション別の群集に占める各種 の個体数割合を用いており, 1 種 1 個体しか出現しなかっ たステーションは解析から除いた。、いずれも IBM 社の解 析ソフトSPSS（ver. 20）を使用し, ステーション間の違い をユークリッド距離によって算出した後, Ward 法により 階層構造を図式化した樹形図（dendrogram）を構成した.

\section{結果}

\section{各干潟の底生生物相と干潟内の分布特性}

各干潟の底生生物相を, 定性的調査及び定量調查の結果 から比較する. 定性的調查, 定量的調査によって 4 干潟で 採集された底生生物は, あわせて 123 分類群であった. 刺 胞動物, 紐形動物, 扁形動物, ユムシ動物, 星口動物, 腕 足動物, 脊索動物が各 1 分類群ずつと棘皮動物が 2 分類群
出現し, 軟体動物が 55 分類群と最も多く, 次いで節足動 物 36 分類群, 環形動物 23 分類群となった.

手花部干潟では, 刺胞動物 1 , 紐形動物 1 , 扁形動物 1 , 軟体動物 44, 環形動物 13, ユムシ動物 1 , 星口動物 1, 節 足動物 23, 腕足動物 1 , 棘皮動物 2, 脊索動物 1 の計 89 分 類群と最も多くの種又は分類群が採集された（Table 2).こ のうち, 定性的調査と定量的調査の両方で採集された分類 群が 44 と約半数であり, 41 グループが定性的調査でのみ 採集された，定量的調査では，ステーションあたり平均 9.5 個体が採集され, 平均個体数密度は, 1396 (個体数 $/ \mathrm{m}^{2}$ ) であった. 定量的調査で最も多くの個体数が採集された最 優占種はコメツキガニ Scopimera globosaであり，ステー ション当たり 1.45 個体が採集された. 分類群別個体数を 見ると，甲殼綱が全体の $50 \%$ を占めていた（Fig. 2).

屋入干潟では, 刺胞動物 1 , 紐形動物 1 , 軟体動物 18 , 環形動物 9, ユムシ 動物 1 , 星口動物 1 , 節足動物 10 , 棘 皮動物 1 , 脊索動物 1 の計 43 分類群の底生生物が確認され た (Table 2). このうち, 定性的調查と定量的調査の両方で 採集された分類群が 16 と半数以下であり, 20 グループが定 量的調査でのみ採集された。 ステーション当たり平均 8.37 個体と最も少なく, 平均個体数密度は, 1231 (個体数 $/ \mathrm{m}^{2}$ ) であった．最優占グループはウミニナ属 Batillaria spp. で ステーション当たり 1.21 個体採集され, 腹足綱と甲殼綱 が多く出現した (Fig. 2).

市干潟では, 軟体動物 12 , 環形動物 15 , 節足動物 11 , 脊 索動物 1 の計 39 分類群の底生生物が確認されたが（Table 2), この数は 4 ヶ所の中で最も少なかった.このうち, 定 性的調查と定量的調査の両方で採集された分類群は 7 と極 めて少なく, 各 16 グループが定性的調查, 定量的調査で のみ採集された。 ステーション当たり平均 10.16 個体が採 集され, 平均個体数密度は 1494 (個体数 $/ \mathrm{m}^{2}$ ) であった. 最優占種はコケゴカイ Simplisetia erythraeensis でステー ション当たり 2.88 個体採集され, 多毛綱と甲殼綱が全体 の $95 \%$ を占めた (Fig. 2).

久根津干潟では, 軟体動物 17 , 環形動物 7, 節足動物 19

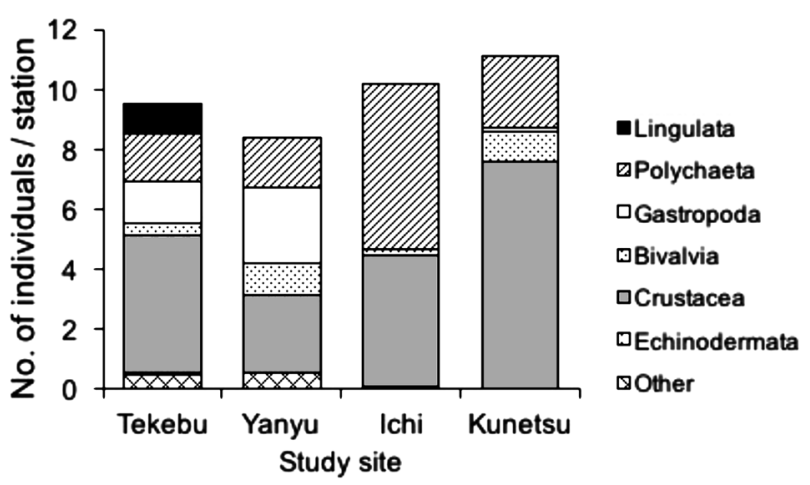

Fig. 2. Macrobenthic community composition at each study site. Numbers of individuals of each taxon at each station $\left(0.068 \mathrm{~m}^{2}\right)$ are shown. 
Table 2. List of benthic species sampled in each mud flat of Amami-Oshima Island. Open circles indicate species sampled only by quantitative survey, and double circles indicate those sampled only by qualitative survey. Filled circles indicate species sampled by both types of survey.

\begin{tabular}{|c|c|c|c|c|c|c|c|}
\hline Phylum & Class & Japanese Name & Species Name & Tekebu & Yanyu & Ichi & Kunetsu \\
\hline Cnidaria & Anthozoa & タテジマイソギンチャク & Haliplanella lineata & O & $\bigcirc$ & & \\
\hline Nemertinea & & 紐形動物門の種 & Anopla spp. & (a) & $\bigcirc$ & & \\
\hline Plathelminthes & & 扁形動物門の種 & Patyhelmlnthes spp. & 0 & & & \\
\hline \multirow[t]{55}{*}{ Mollusca } & Polyplacophora & キクノハナヒザラガイ & Acanthopleura tenuispinosa & (a) & & & \\
\hline & & ヒメケハダヒザラガイ & Acanthochitona achates & (a) & & & \\
\hline & Gastropoda & コウダカアオガイ & Nipponacmea concinna & (a) & 0 & (a) & \\
\hline & & クサイロアオガイ & Nipponacmea fuscoviridis & (a) & & & \\
\hline & & ヒメコザラ & Patelloida pygmaea & & & & (a) \\
\hline & & オキナワイシダタミ & Monodonta labio & (a) & 0 & (1) & (a) \\
\hline & & キヌシダタミ & Ethmonolia nektomica & (a) & & & \\
\hline & & カンギクガイ & Turbo (Lunella) coronoatus coronatus & ()) & 0 & & \\
\hline & & サザエ科の 1 種 & Turbinidae sp. & & $\bigcirc$ & & \\
\hline & & リュウキュウアマガイ & Nerita (Theilostyla) exuvia & (2) & & & \\
\hline & & コシダカアマガイ & Nerita $($ Nerita $)$ striata & (a) & & & \\
\hline & & マルアマオブネ & Nerita (Theilostyla) squamulata & () & 0 & (a) & (a) \\
\hline & & オオマルアマオブネ & Nerita (Theilostyla) chammaeleon & & & (a) & \\
\hline & & イガカノコ & Clithon corona & & (a) & & \\
\hline & & ミツカドカニモリ & Cerithium zenrum & 0 & & & \\
\hline & & カヤミノカニモリ & Clypeomorus bifasciata & & & & O \\
\hline & & オオシマカニモリ & Clypeomorus subbrevicula & 0 & & & \\
\hline & & ゴマフニナ & Planaxis sulcatus & (9) & & & \\
\hline & & ウミニナ属の種 & Batillaria spp. & 0 & & (2) & \\
\hline & & フトヘナタリ & Cerithidea rhizophorarum & () & & & O \\
\hline & & 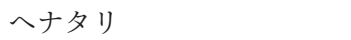 & Cerithidea cingulata & 0 & $\bigcirc$ & & $\bigcirc$ \\
\hline & & ウズラタマキビ属の種 & Littoraria spp. & (9) & & (a) & (a) \\
\hline & & イロタマキビ & Littoraria (Littoraria) pallescens & () & & (a) & \\
\hline & & スジウネリチョウジガイ & Rissoina (Rissolina) costulata & 0 & & & \\
\hline & & ムカデガイ科の 1 種 & Vermetidae sp. & (a) & & & $\bigcirc$ \\
\hline & & ホウシュノタマ & Narica gualteriana & O & & & \\
\hline & & ミツクチキリオレ科の 1 種 & Triphoridae sp. & (9) & & & \\
\hline & & カゴメガイ & Bedeva birileffi & () & & & \\
\hline & & ヨウラクレイシダマシ & Muricodrupa fiscella & (a) & & & \\
\hline & & イボニシ & Thais (Reishia) clavigera & 0 & & & \\
\hline & & イボヨフバイ & Nassaridae coronatus & (a) & & & \\
\hline & & クリイロヤタテ & Strigatella fastigium & & $\bigcirc$ & & \\
\hline & & ムシロガイ科の 1 種 & Nassaridae sp. & & & (1) & \\
\hline & & ウミクダマキ & Clavus (Tylotiella) obliquata & 0 & & & \\
\hline & & ドロアワモチ & Onchidium hongkongense & 0 & 0 & & () \\
\hline & & ヒラカラマツガイ & Siphonaria (Mestosiphon) atra & (a) & & & \\
\hline & Bivalvia & フネガイ & Arca avellana & 0 & & & \\
\hline & & エガイ & Barbatia (Abarbatia) lima & 0 & 0 & & (2) \\
\hline & & イガイ科の 1 種 & Mytilidae sp. & & & & (a) \\
\hline & & クジャクガイ & Septifer bilocularis & 0 & & (a) & \\
\hline & & ヒバリガイモドキ & Hormomya mutabilis & 0 & (a) & & \\
\hline & & イタボガキ科の 1 種 & Ostreidae sp. & (a) & $\bigcirc$ & & \\
\hline & & ウメノハナガイ & Pillucina pisidium & 0 & & & 0 \\
\hline & & ヒシガイ & Fragum bannoi & 0 & & & \\
\hline & & クチバガイ & Coecella chinensis & & & (a) & \\
\hline & & ヌノメイチョウシラトリ & Serratina capsoides & & & $\bigcirc$ & \\
\hline & & ニッコウガイ科 sp.1 & Tellinidae sp.1 & & & & $\bigcirc$ \\
\hline & & ニッコウガイ科 $\mathrm{sp} .2$ & Tellinidae sp. 2 & (2) & & & \\
\hline & & アラスジケマンガイ & Gafrarium tumidum & () & $\bigcirc$ & & 0 \\
\hline & & ヤエヤマスダレ & Katelysia hiantina & (a) & & & \\
\hline & & イオウハマグリ & Pitar sulfureum & 0 & $\bigcirc$ & & $\bigcirc$ \\
\hline & & リュウキュウアサリ & Tapes literatus & (a) & & & \\
\hline & & ヒメアサリ & Ruditapes nariegatus & 0 & & O & \\
\hline & & マルスダレガイ科の 1 種 & Veneridae sp. & 0 & & & 0 \\
\hline & & ソトオリガイ & Laternula marilina & () & 0 & & 0 \\
\hline \multirow[t]{3}{*}{ Annelida } & Polychaeta & ウロコムシ科の種 & Polynoidae spp. & () & () & & \\
\hline & & チロリ科チロリ属の種 & Glycera spp. & & & $\bigcirc$ & \\
\hline & & チロリ科の種 & Glyceridae spp. & 0 & & 0 & 0 \\
\hline
\end{tabular}


Table 2. Continued.

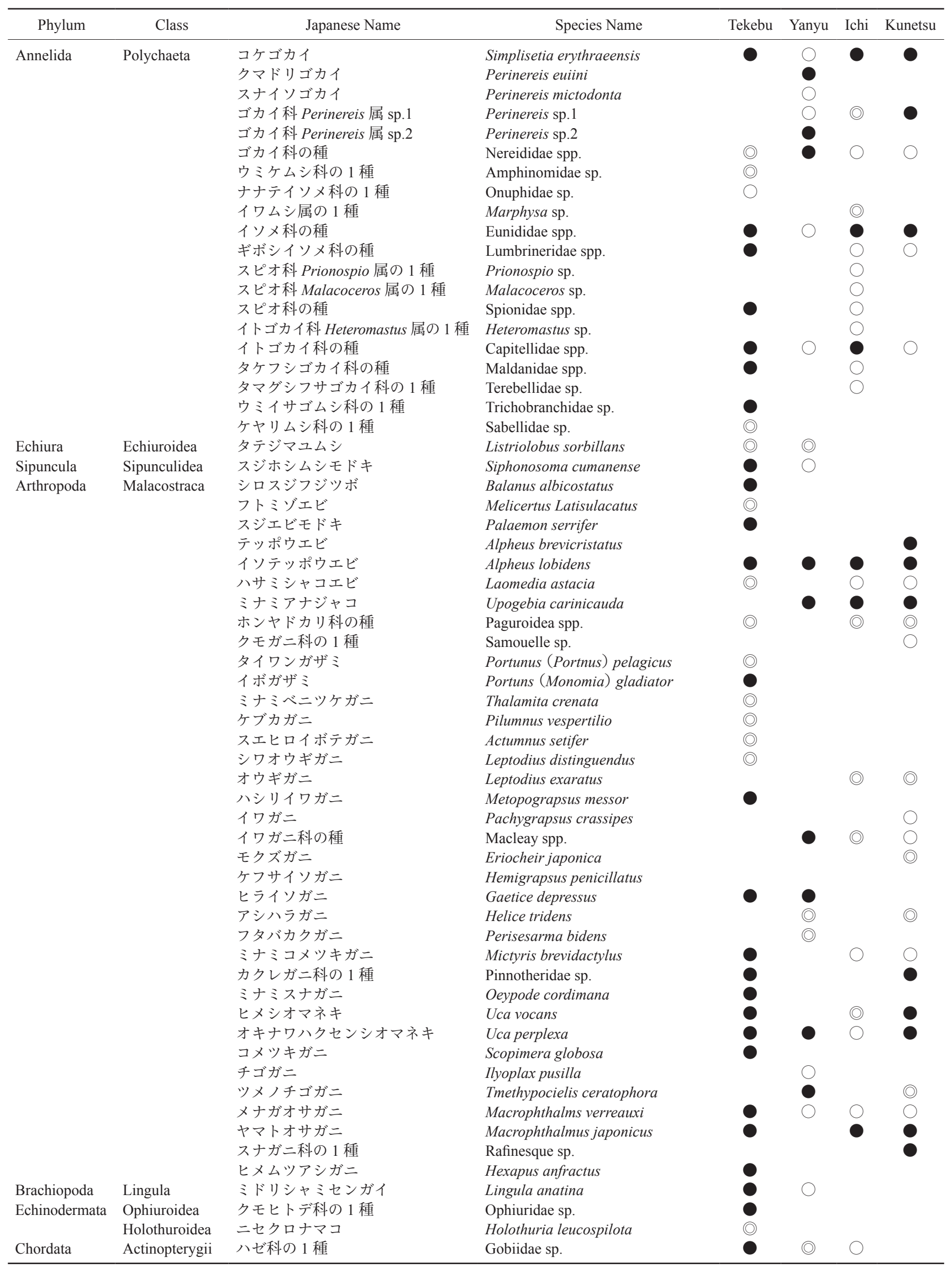




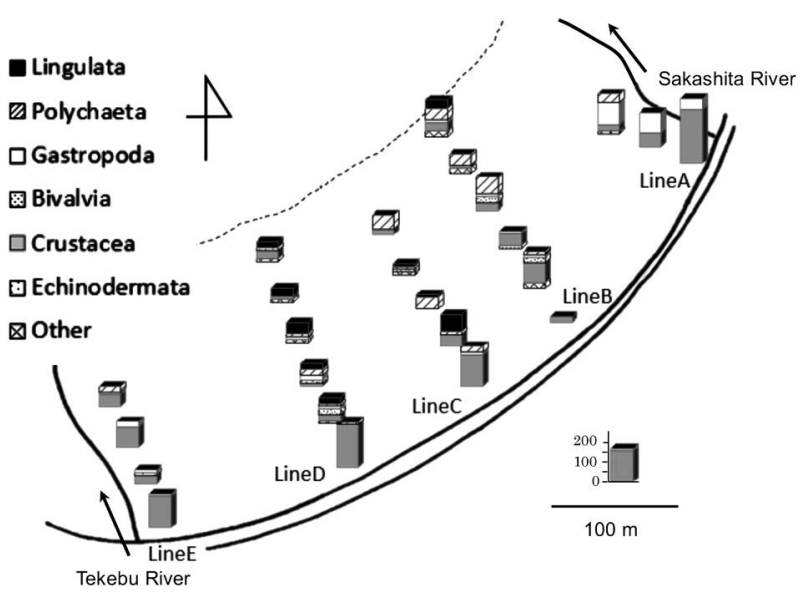

Fig. 3. Distribution of the macrobenthic community at Tekebu-higata. Bars on the map show the locations of each station and the densities $\left(/ \mathrm{m}^{2}\right)$ of each taxon. The solid lines show the land area and rivers and the dashed line indicates the mean low water springs. Arrows indicate the current direction of the Tekebu and Sakashita rivers.

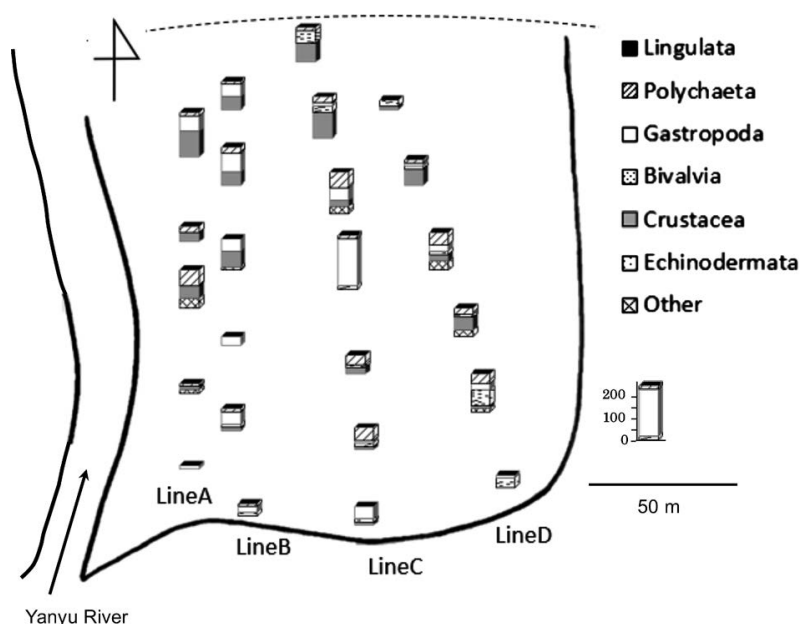

Fig. 4. Distribution of the macrobenthic community at Yanyu-higata. Bars on the map show the locations of each station and the densities $\left(/ \mathrm{m}^{2}\right)$ of each taxon. The solid lines show the land area and river and the dashed line indicates the mean low water springs. Arrows indicate the current direction of the Yanyu River.

の計 43 分類群の底生生物が確認された（Table 2)。このう ち，定性的調查と定量的調查の両方で採集された分類群は 12 と半数以下であり, 19 グループが定量的調査でのみ採 集された。 ステーション当たり平均 11.12 個体と最も個体 数が多く, 平均個体数密度は, 1635 (個体数 $\left./ \mathrm{m}^{2}\right)$ となっ た. 最優占種はミナミアナジャコ Upogebia carinicauda で ステーション当たり 3.13 個体が採集され甲殼綱の個体数 が全体の $70 \%$ を占めた（Fig. 2).

以下，干潟別に分類群ごとの分布をまとめる。手花部干 潟ではライン間で底生生物相がかなり異なっていた（Fig. 3).ライン A では，上部のステーションでは甲殼綱 (シロ スジフジッボ Balanus albicostatus）が優占したが，下部の

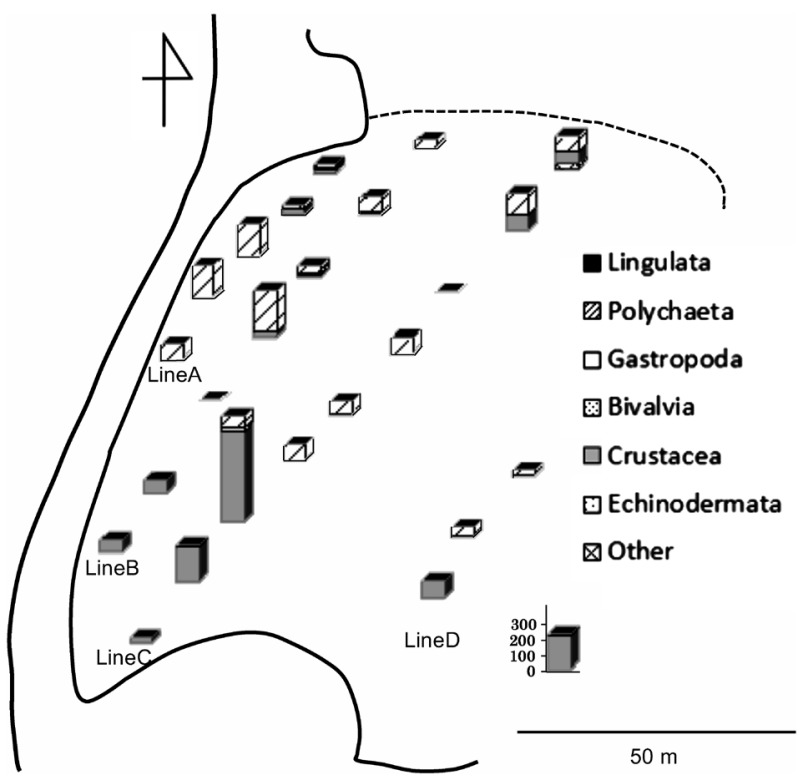

Fig. 5. Distribution of the macrobenthic community at Ichi-higata. Bars on the map show the locations of each station and the densities $\left(/ \mathrm{m}^{2}\right)$ of each taxon. The solid lines show the land area and the dashed line indicates the mean low water springs.

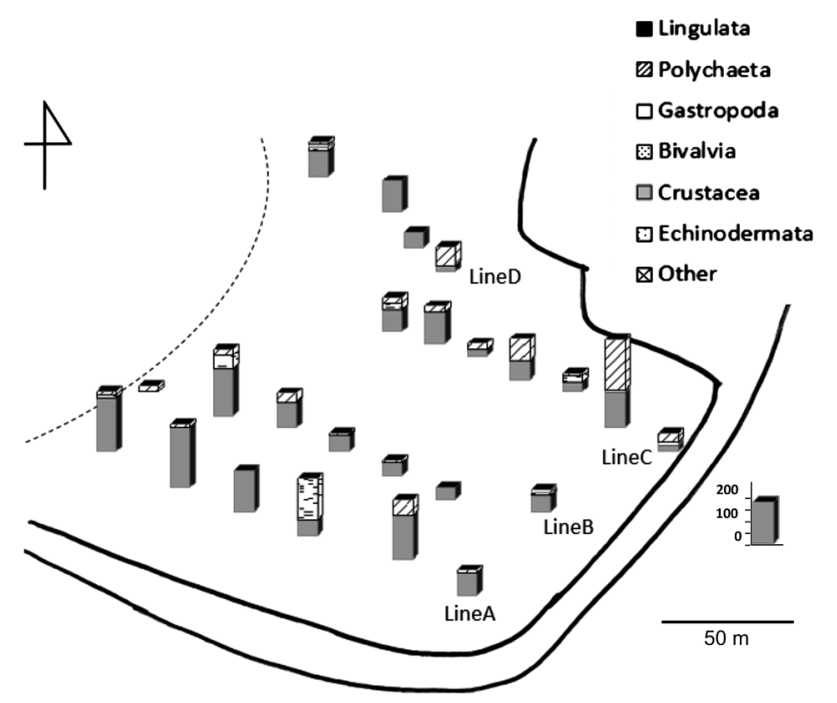

Fig. 6. Distribution of the macrobenthic community at Kunetsuhigata. Bars on the map show the locations of each station and the densities $\left(/ \mathrm{m}^{2}\right)$ of each taxon. The solid lines show the land area and the dashed line indicates the mean low water springs.

ステーションには腹足綱が複数種出現した。ライン B では 6 ステーションで計 53 個体採集され，甲殼綱と多毛綱が 優占した．特に，上部は多毛綱，下部は甲殼綱（イソテッ ポウエビ Alpheus lobidens) が多く出現した。ラインCでは 5 ステーションで計 41 個体採取され，甲殼綱と多毛綱が 優占したが，いずれも複数種が少数個体ずつ出現した。甲 殼綱は上部に多く, 多毛綱はライン上に満遍なく出現した. ラインDでは 6 ステーションで計 52 個体採集され，甲殼 綱と腕足綱が優占した．特に，甲殼綱（ヤマトオサガニ 


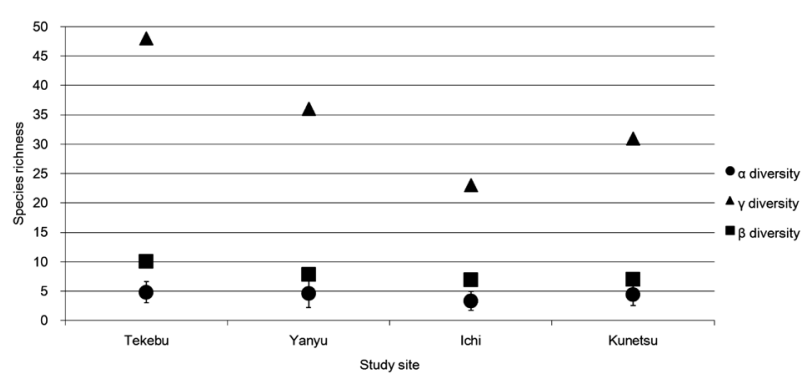

Fig. 7. Spatial components of the macrobenthic community in the four tidal flats.

Table 3. Characteristics of the benthic community in each tidal flat.

\begin{tabular}{lcccc}
\hline & Tekebu & Yanyu & Ichi & Kunetsu \\
\hline$\gamma$ diversity (No. of species) & \multicolumn{1}{c}{48} & \multicolumn{1}{c}{36} & \multicolumn{1}{l}{23} & \multicolumn{1}{c}{31} \\
$\alpha$ diversity & 4.79 & 4.60 & 3.35 & 4.42 \\
$\quad$ (Mean No. of species/station) & & & & \\
$\beta$ diversity & 10.02 & 7.83 & 6.87 & 7.01 \\
Mean No. of individuals/station & 9.58 & 8.04 & 10.04 & 14.63 \\
Shannon-Wiener H' & 3.55 & 3.03 & 2.06 & 2.52 \\
Simpson D & 0.96 & 0.93 & 0.82 & 0.87 \\
\hline
\end{tabular}

Macrophthalmus japonicus）は上部に多く, 腕足綱はライン 上に満遍なく出現した。ライン Eでは 4 ステーションで 計 33 個体採集され, 甲殼綱が複数種出現した。屋入干潟で は, 多毛綱と腹足綱がどのラインでも出現しており（Fig. 4), 主な出現種（グループ）はコケゴカイ, Perinereis 属, ウ ミニナ属であった。ライン C の下部とライン D の上部に は集中的に二枚貝綱（クチバガイ Coecella chinensis）が出 現した。市干潟では，干潟上部ではオキナワハクセンシオ マネキUca perplexa 等の甲殼綱が出現し，下部ではコケゴ カイ等の多毛綱が出現していた。ほかの分類群は干潟全体 を通して，ほとんど出現していない（Fig. 5)。 久根津干潟 では，干潟全体を通して甲殼綱が多く出現していた。ま た，ライン A の中部，ライン B の下部など，局所的に二 枚貝綱（ヒメアサリ Ruditapes nariegatus）が出現していた (Fig. 6).

\section{各干潟における底生生物群集の特性}

ステーションあたりの出現種数で示す $\alpha$ 多様性は, 市干 潟で約 3.4 と小さいことを除けば, いずれの干潟も 4.4 か ら 4.8 の間に収まり, 特に手花部干潟と屋入干潟で大きかっ た (Fig. 7; Table 3). 一方，この 2 海岸ではステーションあ たりの採集個体数が 10 個体未満と少なかったのに対して, 久根津干潟ではその 1.5 倍程度の個体数が採集されている. 干潟全体の多様性を示す $\gamma$ 多様性は, 手花部干潟, 屋入干 潟，久根津干潟，市干潟の順で大きく，48 種から 23 種と 2 倍の違いがあった。 $\beta$ 多様性に関してもこの傾向は変わ らず，手花部干潟では 10 を超えたのに対して市では 6.87 と小さかった。

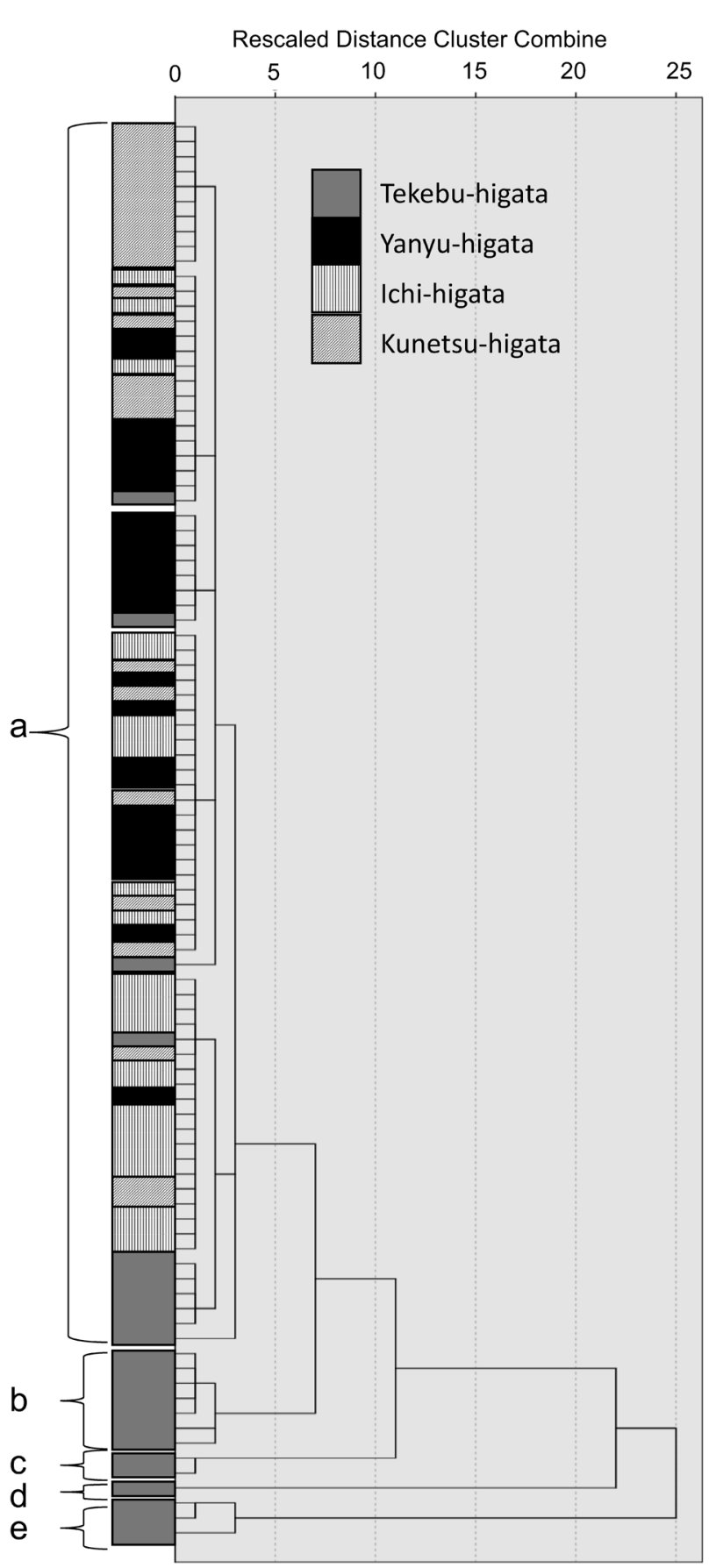

Fig. 8. Cluster analysis of macrobenthic community structure. The highest station in Line B (B- $0 \mathrm{~m})$ was excluded from the analysis because only one individual was sampled here.

Shannon-Wiener の H'は手花部干潟で 3.55, 屋入干潟で 3.03, 久根津干潟で 2.52, 市干潟で 2.06 であり, $\alpha$ 多様性, $\gamma$ 多様性と同様の傾向を示した（Table 3). Simpson の D も 同様の傾向であった。

定量的調査の結果 2 個体以上の底生生物を採集できた 95 ステーションについてクラスター解析を行った結果, 82 ステーションがひとつのクラスターを形成し, 残り 13 ス テーションが4つのクラスターに分割された（Fig. 8). 手 


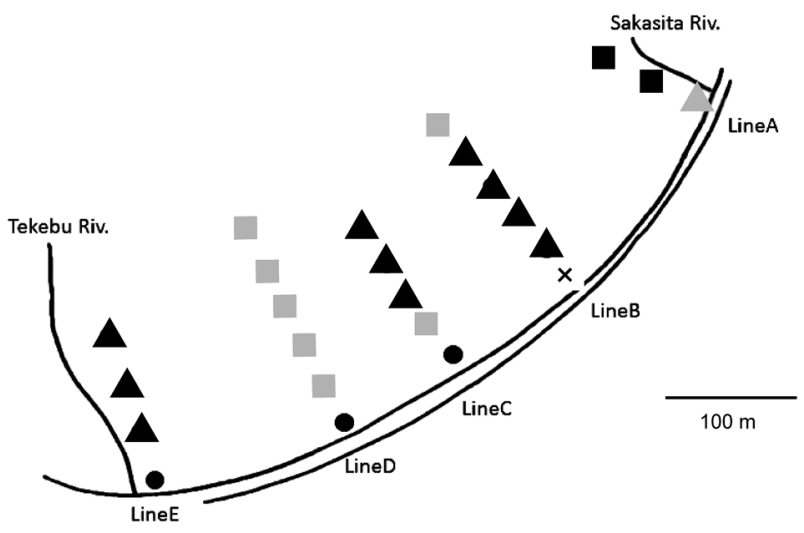

Fig. 9. Spatial structure of the macrobenthic community at Tekebu-higata. Symbols on the map show the position of stations and the groups used for the cluster analysis shown in Fig. 8. Black triangles; cluster a, Gray squares; cluster b, Black squares; cluster c, Gray triangles; cluster d, Circles; cluster e. The cross indicates the station excluded from the cluster analysis (See explanation in the legend to Fig. 8).

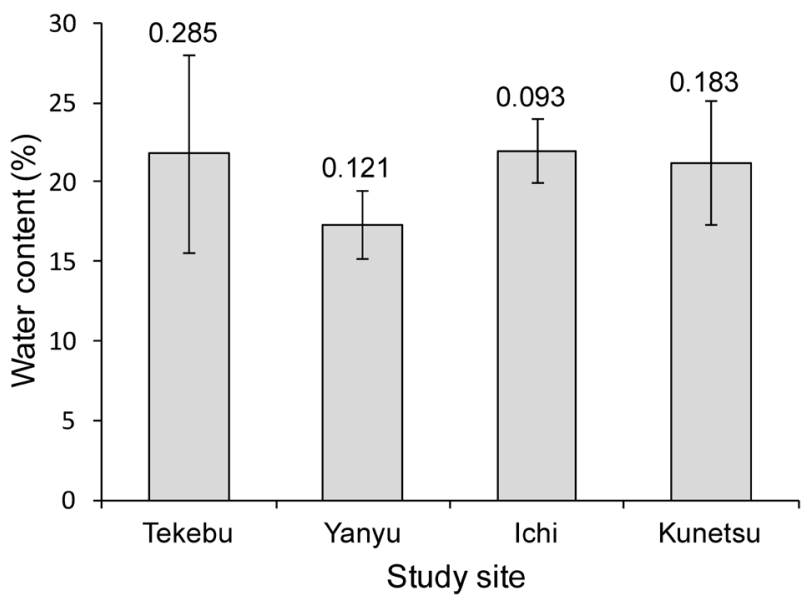

Fig. 10. Sediment water contents in the sediment. Bars show the average of the 24 stations at each tidal flat and vertical lines indicate the standard deviation. Numbers on bars represent the coefficient of variation for each study site.

花部干潟のステーションは全てのクラスターに入ってお り，他の 3 干潟については全てのステーションが一番大き なクラスター（クラスター a）に含まれるという結果で あった。

手花部干潟に関して各クラスターに含まれるステーショ ンの空間配置を見たところ（Fig. 9), 最上部にしか見られ ないクラスターが2つあるほかはライン別にクラスターが 分かれる傾向があり，他の 3 干潟と同じクラスターに含ま れる群集はライン $\mathrm{B}, \mathrm{C}, \mathrm{E}$ で見られた。

\section{各干潟の底質環境とその干潟内空間変異}

ステーション毎に採取した底質サンプルから，含水率， 強熱減量, 中央粒径值を算出し, 干潟ごとに平均した。含 水率は, 屋入干潟だけが平均約 $17 \%$ と低く, 他の干潟は

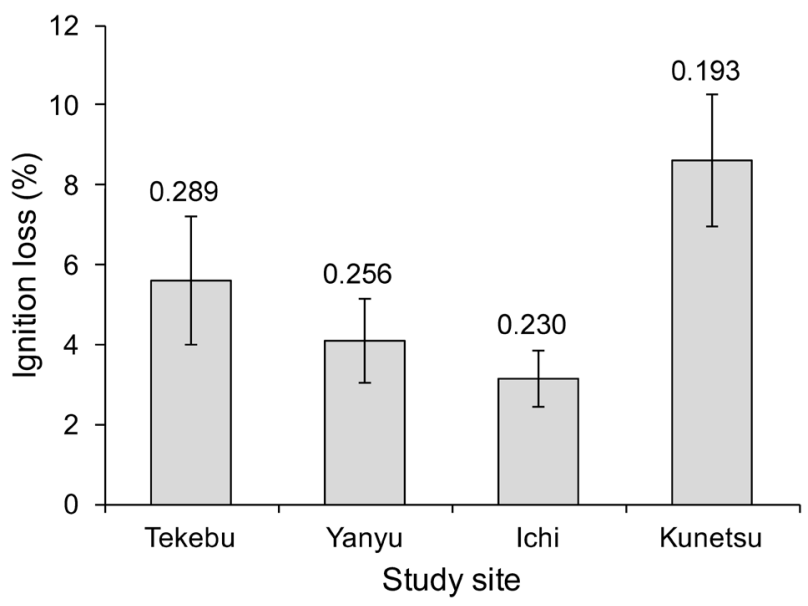

Fig. 11. Organic content measured by ignition loss. Bars show the average of the 24 stations at each tidal flat and vertical lines indicate the standard deviation. Numbers on bars represent the coefficient of variation for each study site.

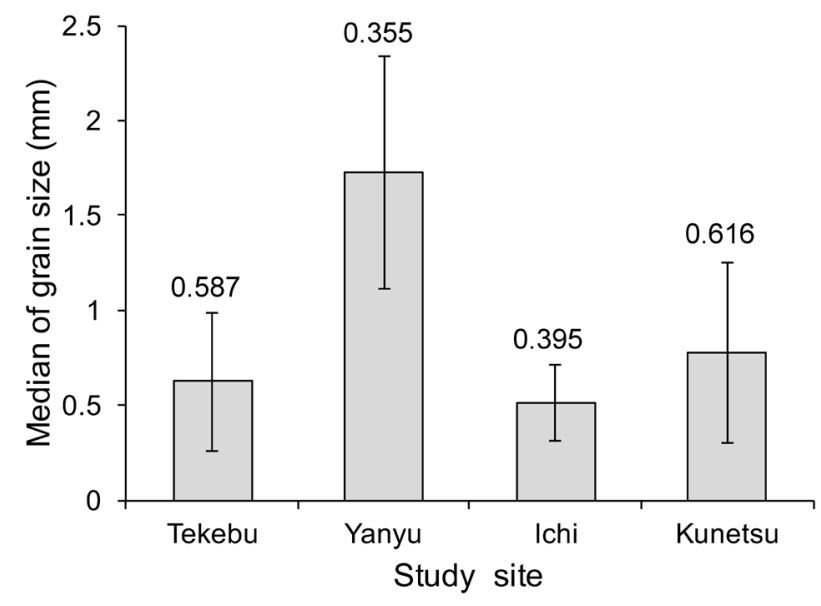

Fig. 12. Median sediment grain size of the sediment. Bars show the average of the 24 stations at each tidal flat and vertical lines indicate standard deviation. Numbers on bars represent the coefficient of variation at each study site.

20\%以上であった（Fig. 10). ステーション間の変異を表 す変動係数は, 手花部干潟で一番大きく, 市干潟が最も小 さかった。

有機物含有量を表す強熱減量は，久根津干潟では $8.62 \%$ と高かったのに対して，一番少ない市干潟では $3.14 \% と$ 半 分以下であった (Fig. 11). 手花部干潟と屋入干潟はその 間の值を取り, 変動係数は含水率と同様手花部干潟で最も 高かった。

中央粒径值は, 屋入干潟で平均 1.728 と飛び抜けて高く, 砂を多く含む底質であることが示された（Fig. 12）．粒径 $2 \mathrm{~mm}$ 以上の粒子が重量の半分以上を占めたため, 中央粒 径值が 2 以上になるステーションも11ヶ所あり, 変動係 数は 4 干潟の中で最も小さかった. 他の干潟に関しては, 市干潟で 0.507 , 手花部干潟で 0.624 , 久根津干潟で 0.777 


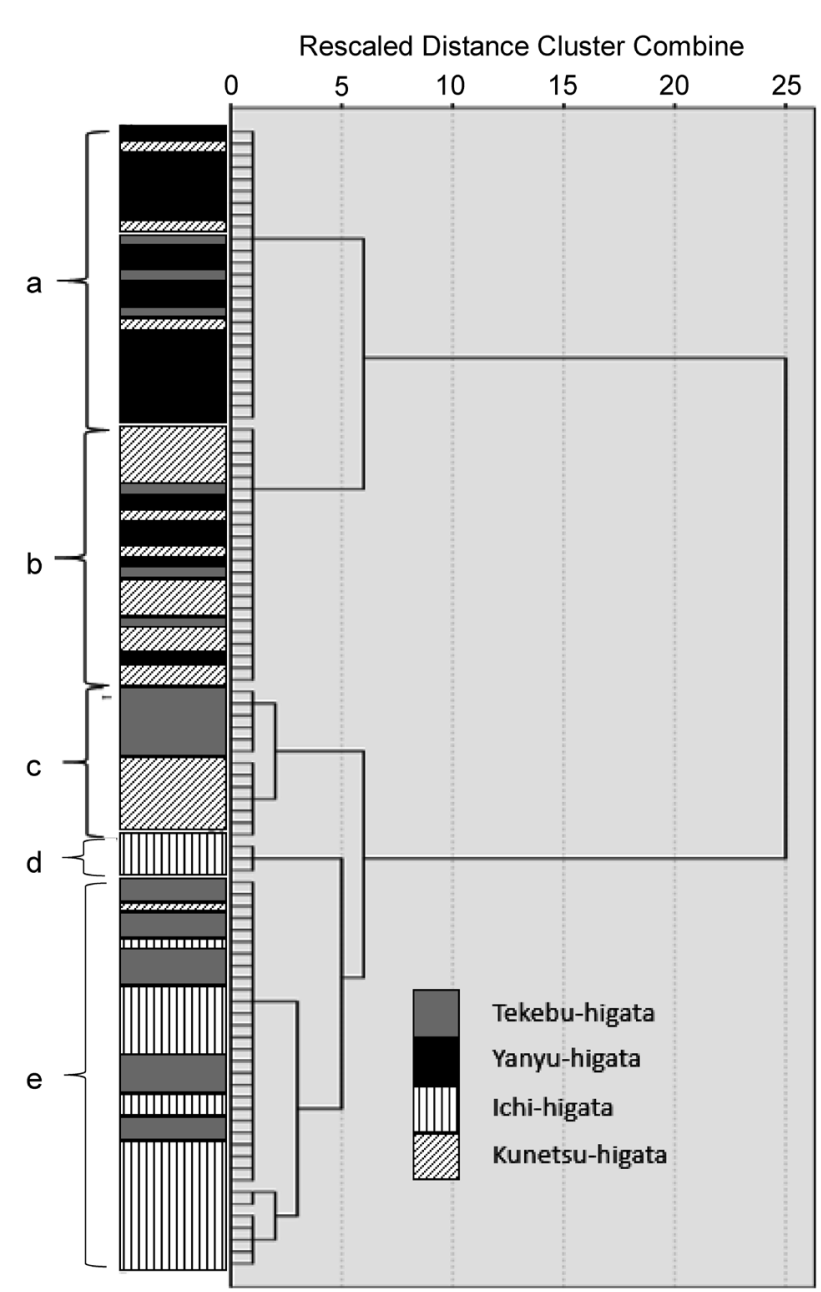

Fig. 13. Cluster analysis of sediment composition based on the particle size composition at each station. The 96 stations were divided into 5 groups, which indicated by letters on the left of the figure.

と比較的平均值は似ていたが, 変動係数は手花部干潟と久 根津干潟で大きくなった。

各粒径クラスの重量割合を用いてクラスター解析を行っ たところ, 96 のステーションは大きく 2 グループに分けら れ (Fig. 13), さらに 2 グループと3グループに分けられた. 屋入干潟は図の上側グループに，市干潟は下側のグループ

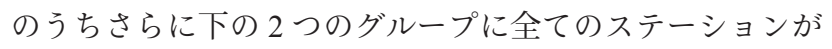
含まれていた，形成されたクラスターを a から e とすると， 手花部干潟は $\mathrm{d}$ 以外の 4 クラスターに, 久根津干潟は a か ら cの3クラスターに含まれていた。

手花部干潟を除く 3 干潟では多くのステーションが単一 のクラスターに含まれており, ライン内の高度やライン間 で粒度組成の違いは見られなかった（Fig. 14）。手花部干 潟に関して各クラスターに含まれるステーションの空間配 置を見たところ，グループ a は河川沿いの潮間帯下部，グ ループ c は潮間帯中部にまとまってみられたが, グループ $\mathrm{b}, \mathrm{d}$ が特定の位置にみられるということはなかった。
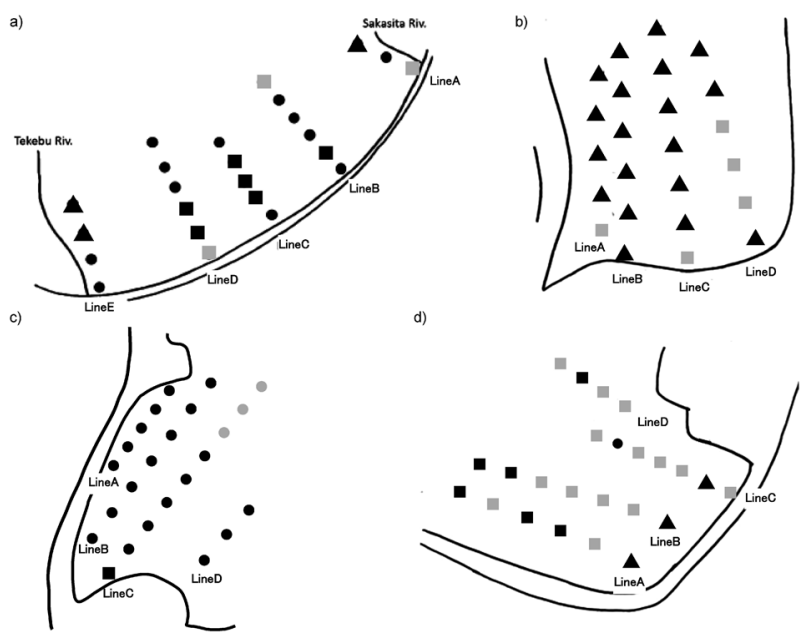

Fig. 14. Spatial structure of sediment composition. (a) Tekebuhigata, (b) Yanyu-higata, (c) Ichi-higata, and (d) Kunetsu-higata. Symbols on the map indicate the positions of the stations and groups used for cluster analysis shown in Fig. 13. Triangles: cluster a, Gray squares: cluster b, Black squares: cluster c, Gray circles: cluster d, Black circles: cluster e.

\section{考察}

奄美大島の干潟における底生生物相を明らかにするため, 島内 4 ヶ所の干潟で, 定量的調査と定性的調査を行った. 計 123 種又は分類群が確認され，うち 55 グループが軟体 動物，36グループが節足動物であった．上野ら（2015）の 研究でも, 南九州の干潟と比較して節足動物特にカ二類の 種多様性が高いことが，奄美大島の干潟における底生生物 相の特徵としてあげられている，今回の調査では，奄美大 島が分布の北限とされている種（環境省自然保護局・生物 多様性センター2007）が5種採集されており，その全て (ツメノチゴガニ Tmethypocielis ceratophora, ミナミコメツ キガニMictyris brevidactylus, オキナワハクセンシオマネ キ, ヒメシオマネキUca vocans, ケフサヒライソモドキ Ptychognathus barbatus）が節足動物であった。哺乳類, 鳥 類, 昆虫類等陸上動物においては, 奄美大島以南と以北で 種組成が大きく変わることから, 東洋区と旧北区という $2 つ$ 生物地理区に分けられ，奄美大島と屋久島の間に横 たわるトカラ列島の小宝島と悪石島の間に位置する境界線 は渡瀬線と呼ばれている. 今回の調査結果から, 陸上動物 だけでなく, 干潟の底生生物においても同様に生物地理学 的な境界線が存在する可能性が考えられる.

本研究で調査した 4 干潟のうち，手花部干潟では 2006 年に第 7 回自然環境保全基礎調査が行われており（環境省 自然保護局・生物多様性センター2007), 同じ笠利湾に面 する喜瀬干潟とあわせて 121 種が採集されている。うち節 足動物が 49 種と最も多かったが, 本研究では 89 種又は分 類群のうち 44 が軟体動物門であった。他の地域で希少と 
されるタテジマユムシ Listriolobus sorbillans, スジホシム シモドキ Siphonosoma cumanense, ミドリシャミセンガイ Lingula anatina などが分布している点, ヒメシオマネキ, コメツキガニ, オキナワハクセンシオマネキ, ミナミコメ ツキガニ, ツメノチゴガニ, ニセクロナマコ Holothuria leucospilota などが多く見られる点などは第 7 回自然環境保 全基礎調査と本研究で共通する結果である.

名和（2008）は手花部干潟, 屋入干潟, 久根津干潟に おいて軟体動物の調査を行った。手花部干潟においては, ニッコウガイ科やマルスダレガイ科二枚貝を中心に 93 種 を採集している.アラスジケマンガイ Gafrarium tumidum やイオウハマグリPitar sulfureum, ソトオリガイ Laternula marilina など中潮帯以上に分布する種は本研究でも採集さ れたが，ヒラザクラ Tellinides ovalis やズングリアゲマキ Azorinus abbreviatus など低潮帯の種は本研究では採集出来 なかった．名和（2008）は屋入干潟で二枚貝を中心に 58 種 の軟体動物を採集しているが, 本調査では軟体動物が 18 種 しか採集されなかった. ウミニナ属, へナタリ Cerithidea cingulata, マルアマオブネ Nerita (Theilostyla) squamulata, カンギクガイ Turbo (Lunella) coronoatus coronatus, オキナ ワイシダタミ Monodonta labio, クチバガイ, ソトオリガイ など, 代表的な種は両方の調査で共通して見られる. 久根 津干潟では, フトヘナタリ Cerithidea rhizophorarum やカヤ ノミカニモリClypeomorus bifasciata, ソトオリガイやアラ スジケマンガイなど名和（2008）が多く採集している種が 本研究においても定量的調査で採集されており，普通種に 関してはよく似た結果となっている.

本調査の結果を干潟間で比較すると, 出現種又は分類群 数が干潟間で大きく異なっており, 平均個体数密度にも違 いが見られた. 出現種又は分類群数は花部干潟, 屋入干 潟, 久根津干潟, 市干潟の順で多く, 前 2 干潟では軟体動 物門が, 市干潟では環形動物門, 久根津干潟では節足動物 門で最も多くのグループが出現した。

最も多くの種又は分類群数が出現した, すなわち多様性 が高いと思われる手花部干潟では, その半数近くが定性的 調査でのみ採集されている。 それに対して, 屋入干潟と久 根津干潟では定量的調査によってのみ採集されたものが比 較的多く, 市干潟では両者同数であった。この結果は, 手 花部干潟は干潟内のハビタット多様性が高く, それぞれの ハビタットに個体数が少なく定量的調査では採集されない ような希少な種が生息する状況であることを示唆してい る.

さらに群集の干潟内空間配置を明らかにするため, 各干 潟 24 ステーションを設置して採集した定量調査の結果に 関して解析を行なった。各干潟で採集された底生生物の種 数, すなわち干潟全域の $\gamma$ 多様性は, 手花部干潟の 48 種か ら市干潟の 23 種まで，大きく異なった（Table 3）。 また， 多様度指数を表す Shannon-Wiener の $\mathrm{H}^{\prime}$ と Simpson の D の 結果においても, 手花部干潟, 屋入干潟, 久根津干潟, 市
干潟の順で多様性が高い結果となった。しかし.1 ステー ションあたりの種数, すなわち $\alpha$ 多様性については, 干潟 間で大きな差はみられなかった。一定面積に共存できる種 の数がある程度限られているという現象は, 岩礁潮間帯で も知られている (Okuda et al. 2004). この場合，ステー ション間の違い，すなわち $\beta$ 多様性によって $\gamma$ 多様性が決ま ると考えられる（宮下・野田2003）。ステーション毎の種 の違いを表す $\beta$ 多様性を算出してみると, 手花部干潟, 屋 入干潟, 久根津干潟, 市干潟の順で大きく, 特に手花部干 潟では他の 3 干潟に比べて高い $\beta$ 多様性を示し, クラスター 解析においても, 他の 3 干潟の 72 ステーションが全て一 つの大きなクラスターに分類されたにも関わらず，手花部 干潟の 23 ステーション（1 種 1 個体しか出現しなかった 1 ステーションを解析から除いたため) は最大のクラスター を含む計 5 つのクラスターに分類された。このことは，手 花部干潟内におけるステーション間の底生生物群集の違い が他の干潟における干潟間の違い以上に大きいことを示し ている，すなわち，局所群集間の変異である $\beta$ 多様性によっ て干潟全体の陊様性が高く維持されていると言える．定 性的調査でのみ採集されたグループが多いという点もま た, 群集構造の空間変異が大きいためと考えられる.

では， $\beta$ 多様性は何によって決まっているのか, 今回は 底質環境から考察する。底生生物, 特に本調査で多く出現 しているスナガニ科の甲殼類は，種別に特定の底質を好む ことが知られている（和田 1982）。今回の調査では, 含水 率, 強熱減量, ともに手花部干潟では変動係数すなわちス テーション間のばらつきが大きく, 市干舄ではステーショ ン間のばらつきが小さい結果となった。また，粒度組成を 元に全てのステーションをクラスター解析によってグルー プ分けしたところ, 市干潟に比べて手花部干潟の 24 ステー ションはより多くのグループに分かれたことから，底質環 境の多様性が高いことが分かった。

粒度組成に基づくクラスター解析でも，ステーション間 の違いは手花部干潟で最も大きいことが示唆されている. 底生生物群集は潮間帯上部を除くと河川からの距離によっ て異なる（即ちライン毎に異なる）傾向があり，粒度組成 からみた底質環境の空間構造ときちんと対応するものでは なかった．この点については粒度以外の生息環境要因も含 めた評価方法を確立し, 生物群集の空間構造との対応を検 討する必要がある。いずれにしても，手花部干潟内の底質 環境に空間変異が大きく，そのことが群集の $\beta$ 多様性に影 響していると考えられる.

今回の研究から, 奄美大島の干潟における底生生物相 が, 節足動物, 軟体動物, 環形動物を中心に多くの種を擁 しており, 特に節足動物では九州南部の種組成と大きく異 なっていることが示唆された。 奄美大島内の各干潟間での 違いも大きく，特に種数で表される種多様性には，2 倍近 い差が見られた。この差は，一定面積内に共存する種数， すなわち $\alpha$ 多様性ではなく，ステーション間の違いである 
$\beta$ 多様性によって決定づけられていると考えられる。また， 底質環境のばらつきが大きい海岸では $\beta$ 多様性が高いこと から, 干潟内における環境変異が $\beta$ 多様性を高め, 干潟全 体の多様性に寄与している可能性が示唆された。

謝辞：本研究を行うにあたり，有益なご助言を下さった野呂忠 秀鹿児島大学名誉教授 (現, 鹿児島県立大学学長), 底質分析に 関してご協力いただきました日高正康講師（当時）（鹿児島大学 水産学部）及び鹿児島大学総合研究博物館にこの場を借りて厚く 御礼申し上げます。最後に，本研究を進めるうえで励ましを下さ り, 野外調查にご協力戴いた研究室の皆様, 同輩の皆様（江川昂 弘さん, 志津馬大起さん, 白澤大樹さん, 森美和さ九, 木下涼さ ん, 古川貴裕さん）に深く感謝申し上げます。なお，本論文の作 成は, 科研費（16K00635）の助成を受けて行われました。

\section{引用文献}

奄美大島生物多様性地域戦略策定運用協議会 2015. 奄美大島生物 多様性地域戦略，奄美市・大和村 - 宇検村 - 瀬戸内町 - 龍郷 町, 鹿児島, 90 pp.

Hirose, K., T. Yorisue, H. Ito, T. Yomoko and S. Kojima 2014. Multiplex PCR-based genotyping of mitochondrial DNA from two species of the genus Batillaria (B.multiformis and B.flectosiphonate) from Amami-Oshima, Japan. Plankton and Benthos Research, 1 (9): 67-70. 鹿児島県環境林務部自然保護課（編）2016. 改訂・鹿児島県の絶 滅のおそれのある野生動植物（動物編），一般財団法人鹿児島 県環境技術協会, 鹿児島, $401 \mathrm{pp}$.

環境庁自然保護局（編）1994. 第 4 回自然環境保全基礎調查 海 域生物環境調査報告書 (干潟, 藻場, サンゴ礁調査), 財団法 人海中公園センター, 東京, $299 \mathrm{pp}$.

環境省自然保護局・生物多様性センター（編）2007. 第 7 回自然 環境保全基礎調査 浅海域生態系調査（干潟調查）業務報告 書, 日本国際湿地保全連合, 東京, $236 \mathrm{pp}$.

菊池泰二 1993. 干潟生態系の特性とその環境保全の意義. 日本
生態学会誌, 43: 223-235.

木村昭一 - 木村妙子 2008. 奄美大島名瀬市街地小河川の貝類相. 日本貝類学会研究連絡誌, 39: 1-14.

木元晋作・武田 博 1989. 群集生態学入門, 共立出版株式会社, 東京, $192 \mathrm{pp}$.

岸野 底・野元彰人 - 木巴聡美 - 米沢俊彦 - 和田恵次 2001. 奄美 大島の汽水性カ二類. 南紀生物, 43: 125-131.

増田 修- 早瀬善正 2000. 奄美大島産陸水性貝類相. 兵庫陸水生 物, 51・52: 305-343.

三浦知之・三浦 要 2015. 加計呂麻島の海岸湿地に生息する甲殼 類と貝類の記録 Nature of Kagoshima, 41: 209-222.

宮下 直・野田隆史 2003. 群集生態学, 東京大学出版会, 東京, $187 \mathrm{pp}$.

名和 純 2008. 西宮市貝類館研究報告 第 5 号 琉球列島の干潟 貝類相（1）奄美諸島，西宮市貝類館，兵庫， $42 \mathrm{pp}$.

日本国際湿地保全連合 2011. 干潟生物の市民調査, 日本財団, 東 京, $58 \mathrm{pp}$.

日本ベントス学会 (編) 2012. 干潟の絶滅危惧動物図鑑, 東海大 学出版会, 神奈川, $285 \mathrm{pp}$.

Okuda T., T. Noda, T. Yamamoto, N. Ito and M. Nakaoka 2004. Latitudinal gradient of species diversity: multi-scale variability in rocky intertidal sessile assemblages along the Northwestern Pacific coast. Population Ecology, 46: 59-170.

上野綾子・緒方沙帆・佐藤正典・山本智子 2015. 奄美大島と九州 南部の干潟底生生物群集. Nature of Kagoshima, 41: 287-294.

山本智子・小玉敬興 2009. 過去 60 年間における鹿児島湾奥の海 岸線の変化. Nature of Kagoshima, 35: 55-57.

山本智子・栘屋 藍・松下耕治・佐藤正典 2009. 鹿児島湾の重富 干潟における底生動物相の変化一1994 年と 2005 年の比較一. ベントス学会誌, 64: 32-44.

ラファエリD.・S. ホーキンズ 1999. 潮間帯の生態学 (上). 朝倉 彰 (訳), 文一総合出版, 東京, $311 \mathrm{pp}$.

和田恵次 1982. コメツキガニとチゴガニの底質選好性と摂餌活 動. ベントス研究会連絡誌, 23: 14-26.

WWF ジャパン 2009. 南西諸島生物多様性評価プロジェクト報告 書，世界自然保護基金ジャパン，東京， 178 pp. 